\title{
Nanoceria alleviate oxidative and nitrosative stress in salivary glands glutamate-induced obesity rats
}

\author{
L.P. Hordiienko ${ }^{1}$, T.V. Beregova ${ }^{1}$, K.S. Neporada ${ }^{2}$, T.M. Falalyeyeva ${ }^{1}$, N.M. Zholobak ${ }^{3}$, \\ O.B. Shcherbakov ${ }^{3}$, R.V. Bubnov ${ }^{3}$, M.Ya. Spivak ${ }^{3}$ \\ ${ }^{1}$ Taras Shevchenko National University of Kyiv; \\ ${ }^{2}$ HSEE of Ukraine "Ukrainian Medical Stomatological Academy", Poltava; \\ ${ }^{3}$ Zabolotny Institute of Microbiology and Virology; e-mail: rostbubnov@gmail.com
}

\begin{abstract}
The aim was to study the effects of nanoceria on pro / antioxidant balance in the tissues of salivary glands in glutamate (MSG)-induced obese rats. We included 48 Wistar rats of both genders and divided into four groups, and conducted comparative assessment of intragastric administration of nanocrystalline cerium dioxide at a dose of $1 \mathrm{mg} / \mathrm{kg}$ at the background of glutamate-induced obesity. We determined the total activity of NO-synthase, the maintenance of nitrites, the content of TBA-reactive substances, the content of oxidative modified proteins and catalase activity in the homogenate of salivary glands'tissues of rats. Intragastric administration of nanocrystalline cerium dioxide prevents impairment of pro/antioxidant equilibrium in the tissues of salivary glands of rats on the background of MSG-indused obesity. Intragastric administration of nanocrystalline cerium dioxide on the background of MSG-indused obesity significantly reduces the total NO-synthase activity and the nitrate anions content in salivary gland tissues of rats compared to the group of animals without correction. MSG-induced obesity leads to oxidative stress development in the salivary glands of rats. Administation of nanoceria contributes to the correction of pathological changes in salivary glands via restoring pro/antioxidant balance and preventing the activation of NO-ergic system. Key words: nanocrystalline cerium dioxide; obesity; salivary glands; oxidative stress; obesity complications; monosodium glutamate; food additives; animal model.
\end{abstract}

\section{INTRODUCTION}

Obesity is one of the most widespread public health problems worldwide. According to WHO more than 1.9 billion adults, 18 years and older, are overweight. Of these over 600 million were obese. In 2014, an estimated 41 million children under the age of 5 years were overweight or obese [1,2]. Obesity is characterized by an abnormal excess of white adipose tissue, which is a major risk factor for the development of severe diseases, namely, diabetes mellitus type 2, cardiovascular diseases and cancer. Excessive energy intake, physical inactivity, and genetic susceptibility are main causal factors for obesity, while gene mutations, endocrine disorders, medication, or psychiatric illnesses may be underlying causes in some cases [1, 3]. Uncontrolled use of food addictives may contribute to the onset of obesity. MSG (E621) is a flavor enhancer largely used in the food industry with individual consumption steadily increasing worldwide. As a flavor enhancer, MSG increases the sapidity of food. MSG produces a flavor that cannot be provided by other foods. It elicits a taste described in Japanese as umami, which is translated to "savory" [4]. Higher amounts of individual MSG consumption are associated with risk of being overweight of other major determinants. Studies providing the evidence of MSG toxic effects have raised the increasing interest in MSG intake as flavor enhancer. Neurotoxic effects in brain, obesity and metabolic defects, „Chinese restaurant syndrome“, associated with MSG intake, are among most discussed isssues [4-6].

(C) L.P. Hordiienko, T.V. Beregova, K.S. Neporada, T.M. Falalyeyeva, N.M. Zholobak, O.B. Shcherbakov, R.V. Bubnov, M.Ya. Spivak 
Scientific evidence suggests association between obesity and oral diseases. General health and oral health shares similar causes and behaviour mechanisms, and the self perceived oral health of an individual has been related to general health [7]. Obesity is associated with hyposalivation, development of xerostomia, increased viscosity of saliva [8]. Salivary gland dysfunction leads to the development of caries, pathological processes of oral mucosa and periodontal tissues and causes violation of the digestive processes in other parts of the gastrointestinal tract in the obese patients [9, 10]. Pathological mechanisms involved in the impact of obesity to salivary glands are not fully established.

It is known that oxidative stress is one of main factors in the pathogenesis of obesityrelated diseases [11]. One of its primary characteristics is the cellular imbalance between endogenous antioxidant defenses and reactive oxygen species (ROS) generation inside the cells [12]. Several mechanisms have been suggested to explain the enhanced oxidative stress observed in obese subjects, including altered lipid and glucose metabolism, chronic inflammation, tissue dysfunction, hyperleptinemia, and abnormal post-prandial ROS generation [11].

Currently, free-radical oxidation is regarded as a universal mechanism of regulation basement membrane-dependent processes and cell functions. On the other side, it is a non-specific mechanism of damage of cellular structures, biomolecules, leading to violation of cell metabolism and apoptosis or necrosis [13].

Overtly, obesity is one of the primary challenges to public health, with consequences affecting many different areas of life, and hence the necessity for immediate preventive action [7]. The studies which brought the evidence about the deleterious effects of MSG administration led to further research of potential protective effects of different molecules, especially antioxidants [4].

In recent years, the interest of scientists to the nanotechnology, which can improve phar- macological therapies, is growing [14]. Nanocrystalline cerium dioxide (ceria nanoparticles, nanoceria, $\mathrm{NDC}, \mathrm{nCeO}_{2}$ ) has shown promise as a therapeutic application due to its antioxidant auto-regenerative ability and low toxicity. The electronic structure of NDC at the nanoscale leads to its antioxidant activity. Both large surface-area-to-volume ratio with the reduction in particle size and ability to reversibly switch between $\mathrm{Ce}^{3+}$ and $\mathrm{Ce}^{4+}$ present on the surface result in the formation of oxygen defects in the crystal lattice that act as "reactive sites" for free radical scavenging $[16,17]$.

Recent evidence suggests that NDC slows the progression of degeneration of retina [18], has antioxidant properties in brain tissues [19] fibroblasts of human skin [20] and endothelial cells [21]. Antioxidant properties of nanoceria in digestive tract have not been deeply studied yet.

Recently we have demonstrated [22] that MSG-induced obesity triggers periodontal tissues alteration on rat model. Using nanoceria contributes to correction of pathological changes in periodontal tissues in glutamateinduced obese rats via balancing proteininhibitory capacity, reducing depolymerization of fucosylated proteins and proteoglycans and antioxidative activity. However, pathogenetic mechanisms of changes in salivary glands under the experimental obesity has not yet been completely elucidated and the ability to correct these changes with nanocrystalline cerium dioxide.

The aim of the study was to to investigate the influence of nanoceria on pro/antioxidant balance in the tissues of salivary glands in MSGinduced obese rats.

\section{METHODS}

Research was conducted in compliance with the standards of the Convention on Bioethics of the Council of Europe's 'Europe Convention for the Protection of Vertebrate Animals' used for experimental and other scientific purposes' (1997), the general ethical principles of animal experiments, approved by the First National 
Congress on Bioethics Ukraine (September 2001) and other international agreements and national legislation in this field. Animals were kept in a vivarium that was accredited in accordance with the "standard rules on ordering, equipment and maintenance of experimental biological clinics (vivarium)"'. All instruments used for research were the subject for metrological control.

The study was carried out on on 48 rats of both genders. The animals were divided into four groups: I - intact control (4-month rat) newborn rats; group II subcutaneously in a volume of 4 $\mathrm{mg} / \mathrm{g}$ MSG administered at 2, 4, 6, 8, 10 day life, group III - intragastric administration of nanocrystalline cerium dioxide [23] at a dose of $1 \mathrm{mg} / \mathrm{kg}$ volume of $2.9 \mathrm{ml} / \mathrm{kg}$ against the background of glutamate-induced obesity, the fourth group of animals treated with a solution of sodium citrate intragastrically in volume of $2.9 \mathrm{ml} / \mathrm{kg}$ (solvent of nanocrystalline cerium). Introduction of nanocrystalline cerium dioxide solution starting from 4 weeks after birth (after weaning from the mother) and continued intermittently two-week course in 2 weeks.

The changes in a body weight were analyzed in rats of all groups during 4 months. Fourmonth-old animals were decapitated, removed and weighed visceral fat was measured. Body length was measured; body mass index (BMI) (the ratio of body weight $(\mathrm{g})$ of rats to the square of the body length $\left.\left(\mathrm{cm}^{2}\right)\right)$ and Lee obesity index
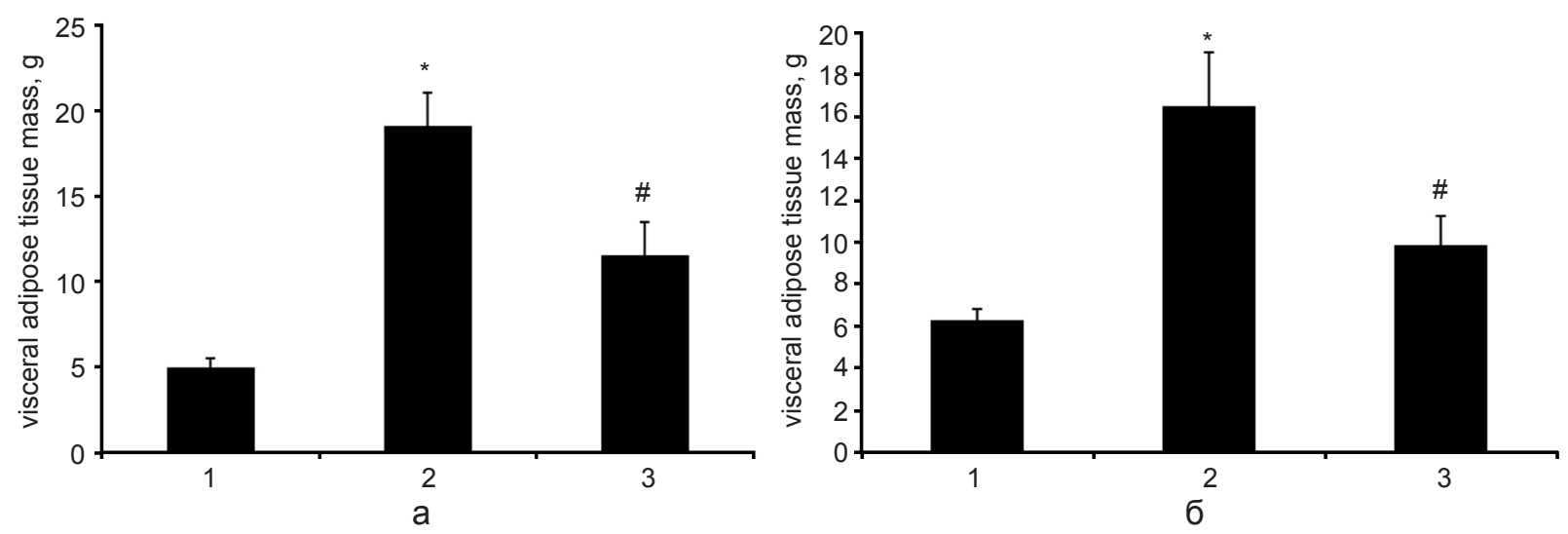

Figure 1. Visceral adipose tissue mass in condition of $\mathrm{MSG}$-obesity and $\mathrm{nCeO}$ treatment $(\mathrm{A}-$ male; $\mathrm{B}-\mathrm{female} ; * * * \mathrm{P}<0.001$ in comparison with 1 group; \# $\mathrm{P}<0.05$ in comparison with 2 group): 1 . Control; 2. $\mathrm{MSG} ; 3$. $\mathrm{MSG}+\mathrm{nCeO}_{2}$ 
biologically active substances of adipose tissue (adipokines) perform inflammatory function and produce ROS themselves, causing oxidative stress, therefore adipose tissue is considered an independent factor in the generation of systemic ROS [28]. Our research is in compliance to the results obtained by Rocca et al. [29] demonstrating that nanoceria were proven to interfere with the adipogenic pathway by reducing the mRNA transcription of genes involved in adipogenesis, and by hindering the triglycerides accumulation in 3T3-L1 pre-adipocytes. Furthemore, the preliminary research results $[28,29]$ are so promising that they represent an important step towards the potential pharmaceutical use of cerium oxide nanoparticles in the treatment of obesity.

We determined that under conditions of MSG-induced obesity the total NO-synthase activity was 1.57 times greater $(\mathrm{P}<0.05)$ and the maintenance of nitrites was 1.21 times greater $(\mathrm{P}<0.05)$ than control group. Thus, the activation of NO-ergic system in the submandibular salivary gland tissues causes the oxidative stress development due to the formation of cytotoxic peroxynitrate. Intragastric treatment with nanoceria significantly reduces the total activity NO-synthase and nitrate anions content compared to the group of animals without correction (Table 1 ).

Thus, nanocrystalline cerium dioxide prevents the activation of NO-ergic system in the submandibular salivary gland tissues under the conditions of MSG-induced obesity in rats.
The level of TBA-reactive substances is one of the biochemical markers of oxidativeantioxidative balance [15]. We revealed that MSG-induced obesity leads to significant increased of TBA-reactive substances content in submandibular salivary gland tissues in 1.57 times compared to control animals (Table 2). We determined significant increasing of oxidative modified proteins in 1.51 times $(p<0.05)$ in the tissues of submandibular salivary glands of rats compared with the control group. Inactivation of enzymes and hypersensitivity of modified proteins to proteolysis are the most important consequences of oxidative modification of proteins $[11,15]$.

Thus, MSG-induced obesity leads to the activation of free radical oxidation in salivary gland tissues of rats.

We revealed that under intragastric administration of nanocrystalline cerium dioxide the content of TBA-reactive substances significantly decreased by 1.42 times, parallel with the significantly decreased OMP content by 1.3 times compared with the group without correction (Table 2). The results suggest reduction of reactive oxygen species accumulation under nanocrystalline cerium dioxide administration, which acts as a strong antioxidant. Catalase is one of the key enzymes which converts hydrogen peroxide to water and oxygen and protects against oxidative stress development [30]. It was established that under MSG-induced obesity the activity of catalase was significantly decreased

Table 1. The total activity of NO- synthase and the content of the nitrites in the tissues of submandibular salivary glands of rats under glutamate-induced obesity and correction by NDC $(\mathrm{M} \pm \mathrm{m})$

\begin{tabular}{l|c|c|}
\hline \multicolumn{1}{|c|}{ Groups of animals } & $\begin{array}{c}\text { The total activity NO- synthase } \\
\text { activity, }\left[\mathrm{NO}_{2}^{-}\right] \mu \mathrm{mol} / \mathrm{g} * \mathrm{~min}\end{array}$ & Content of the nitrites, $\mu \mathrm{mol} / \mathrm{g}$ \\
\hline 1. Control $(\mathrm{n}=18)$ & $3.23 \pm 0.24$ & $0.834 \pm 0.027$ \\
2. Obesity $(\mathrm{n}=12)$ & $5.07 \pm 0.65$ & $1.013 \pm 0.034$ \\
3. Obesity + NDC $(\mathrm{n}=12)$ & $3.49 \pm 0.17$ & $0.714 \pm 0.027$ \\
4. Obesity + NDC solvent $(\mathrm{n}=6)$ & $5.85 \pm 0.3$ & $1.07 \pm 0.049$ \\
& $\mathrm{P}_{1-2}<0.05$ & $\mathrm{P}_{1-2}<0.05$ \\
& $\mathrm{P}_{2-3}<0.05$ & $\mathrm{P}_{2-3}<0.05$ \\
& $\mathrm{P}_{1-3}>0.05$ & $\mathrm{P}_{1-3}<0.05$ \\
& $\mathrm{P}_{3-4}<0.05$ & $\mathrm{P}_{3-4}<0.05$ \\
\hline
\end{tabular}


Table 2. Index of oxidative stress in the tissues of submandibular salivary glands of rats under conditions of glutamateinduced obesity and correction by NDC $(\mathrm{M} \pm \mathrm{m})$

\begin{tabular}{l|c|c|c|}
\hline Groups of animals & $\begin{array}{c}\text { Content of TBA-reac- } \\
\text { tive substances, } \mu \mathrm{mol} / \mathrm{g}\end{array}$ & $\begin{array}{c}\text { Content of the oxidative } \\
\text { modified proteins, c.u. }\end{array}$ & $\begin{array}{c}\text { The activity of catalase, } \\
\mathrm{nkat} / \mathrm{g}\end{array}$ \\
\hline 1. Control $(\mathrm{n}=18)$ & $72.9 \pm 3.9$ & $0.171 \pm 0.017$ & $6.22 \pm 0.46$ \\
2. Obesity $(\mathrm{n}=12)$ & $114.19 \pm 2.4$ & $0.259 \pm 0.01$ & $4.64 \pm 0.17$ \\
3. Obesity + NDC $(\mathrm{n}=12)$ & $80.53 \pm 2.8$ & $0.2 \pm 0.007$ & $5.97 \pm 0.16$ \\
4. Obesity + NDC solvent $(\mathrm{n}=6)$ & $121.8 \pm 5.5$ & $0.328 \pm 0.01$ & $4.62 \pm 0.36$ \\
& $\mathrm{P}_{1-2}<0.05$ & $\mathrm{P}_{1-2}<0.05$ & $\mathrm{P}_{1-2}<0.05$ \\
& $\mathrm{P}_{2-3}<0.05$ & $\mathrm{P}_{2-3}<0.05$ & $\mathrm{P}_{2-3}<0.05$ \\
& $\mathrm{P}_{1-3}>0.05$ & $\mathrm{P}_{1-3}>0.05$ & $\mathrm{P}_{1-3}>0.05$ \\
& $\mathrm{P}_{3-4}<0.05$ & $\mathrm{P}_{3-4}<0.05$ & $\mathrm{P}_{3-4}<0.05$ \\
\hline
\end{tabular}

by 1.34 times in submandibular salivary glands of rats compared to control (Table 2). High levels of hydrogen peroxide are actually considered more dangerous to cellular homeostasis than high levels of superoxide anion, because hydrogen peroxide is involved in the generation of the highly damaging hydroxyl radicals through the Fenton reaction with metals [31]. Under the administation of nanoceria catalase activity was significantly increased by 1.29 times in submandibular salivary glands compared to the group of animals without correction (Table 2).

Thus, nanocrystalline cerium dioxide administration improves the oxidative-antioxidative balance in the submandibular salivary gland tissues under the glutamate-induced obesity in rats.

\section{DISCUSSION}

Salivary glands are responsible for maintaining oral cavity homeostasis. Their dysfunction results in a change of the composition and amount of saliva provided to the oral cavity. If the pathology occurs for a longer period of time, these changes may impair oral health [32]. In the present study we established the role of oxidative stress in the pathogenesis and development of salivary glands pathology in MSG-induced obese rats as evidenced by significant increasing of TBA-reactive substances and OMP content and significant decresing of catalase activity compared with the control group.
Low levels of ROS are involved in the important signaling pathways regulating key biological responses, including cell migration, mitosis and apoptosis [33]. For instance, endogenous oxidants protected the vasculature by inhibiting endothelial exocytosis that would otherwise lead to vascular inflammation and thrombosis, because endogenous hydrogen peroxide inhibited thrombin-induced exocytosis of granules from endothelial cells [34].

Excessive ROS formation damages cells by starting chemical chain reactions such as lipid peroxidation or by oxidizing DNA or proteins as well as disrupts cellular metabolism including altered gene expression, signal transduction, cell growth, and apoptosis [11, 15]. In salivary glands, ROS are involved in alteration of the functions. Oxidative stress demonstrated to induce alteration of secretory function of the rat submandibular gland, because reduction of submandibular saliva components such as protein and calcium was observed in the rat treated with lead acetate, which induces oxidative stress [35]. Irradiation, a major treatment modality administered for head and neck cancer, induces hypofunction of the salivary glands and consequent xerostomia, in which ROS are believed to be involved in the hypofunction [36].

Lipid peroxidation is the most sensitive marker of oxidative damage which is related to the fact that lipids are very easily and immediately oxidized. The lipid peroxidation process changes the physical properties of the cell 
membranes; it reduces the hydrophobic interior, damages the spatial organization of the lipid membrane, as well as affects various cellular functions and pathways. Moreover, oxidation of lipids components leads to the lipid radical species that may damage other biomolecules $[15,37]$.

Oxidatively modified proteins caused by ROS, not only changes the amino acid residues, but also violates tertiary structure of proteins and even cause their aggregation and denaturation [15] in the tissues of salivary glands of rats leading to the reduction of their functional activity (enzymatic, regulatory, participation in the protein synthesis, transport of ions and lipids).

This is the first study demonstrating that application of nanoceria under conditions of MSG-induced obesity restores oxidative / antioxidant status in salivary glands of rats. These changes of oxidative-antioxidative balance were associated with the significant decreasing of TBA-reactive substances and OMP content and significant increase of catalase activity in the submandibular salivary glands compared with the group without correction.

In the present study we clearly demonstrated the marked elevation in the activity of NOsynthase and the maintenance of nitrites leading to nitrosative stress in the salivary gland under MSG-indused besity. Excessive production of NO contributes to the formation of peroxynitrite which interacts with lipids, DNA, and proteins via direct oxidative reactions or via indirect, radical-mediated mechanisms. These reactions trigger cellular responses ranging from subtle modulations of cell signaling to overwhelming oxidative injury, committing cells to necrosis or apoptosis. According to scientific publications, prolonged excessive formation of nitric oxide and nitrite ions in the salivary glands leads to inhibition of saliva secretion and hypofunction of salivary glands [38].

It is known that antioxidants can be natural (bioantioxidants) and synthetic. There are such deficiencies of antioxidants as poor water solubility, ineffective permeability in the gastroin- testinal tract and instability in storage. Synthetic antioxidants have movable hydrogen atom, and therefore react with free radicals and catalysts of free radical oxidation, primarily with metal ions of variable valence. Nanoceria belongs to this type of antioxidants. It can change valence from $\mathrm{Ce}^{3+}$ to $\mathrm{Ce}^{4+}$. The process takes place in several stages, resulting in oxidation of NDC followed by regeneration to the original state [39]. It is specific and very important property of this material. Traditional antioxidants (ascorbic acid, tocopherol, etc.) can only participate in a redox cycle, then moving in oxidative state or destroyed. Probably the NDC in this aspect takes precedence over existing antioxidants and in some cases exceeds them in their activity. In addition, the toxicity of NDC was reported as low [40]. Therefore, obtained results can be used for creation of drugs based on NDC for preventing or reducing oxidative stress in salivary glands under conditions of obesity.

As a potential limitation of current research in regards to association to obesity a direct pro-oxidative properties glutamate in salivatory glands might be considered due to the ability to initiate a cell death program called oxytosis [39].

\section{CONCLUSIONS}

1. The introduction of monosodium glutamate to newborn rats evokes visceral obesity development in adulthood. Administration of nanoceria reduces visceral tissue mass in MSG-treated rats.

2. Under MSG-induced obesity there is activation of NO-ergic system in salivary glands of rats as evidenced by marked elevation in the total activity of NO-synthase and the maintenance of nitrites. Nanocrystalline cerium dioxide prevents the activation of NO-ergic system in the salivary gland tissues under the glutamateinduced obesity in rats.

3. Administration of nanoceria restored pro/ antioxidant equilibrium in the salivary gland tissues under the glutamate-induced obesity in rats. We suppose that obtained data are associated with the strong antioxidant action of the studied 
substance. Nanocrystalline cerium dioxide attenuates the ROS processes in salivary glands that can prevent injury of salivary glands under conditions of obesity.

The authors of this study confirm that the research and publication of the results were not associated with any conflicts regarding commercial or financial relations, relations with organizations and/or individuals who may have been related to the study, and interrelations of coauthors of the article.

\section{Л.П. Гордіснко ${ }^{1}$, Т.В. Берегова ${ }^{1}$, К.С. Непорада ${ }^{2}$, Т.М. Фалалєєва ${ }^{1}$, Н.М. Жолобак ${ }^{3}$, О.Б. Щербаков ${ }^{3}$, Р.В. Бубнов ${ }^{3}$, М.Я. Співак ${ }^{3}$ \\ НАНОЦЕРІЙ ЗНИЖУС ОКИСНИЙ ТА НІТРОЗАТИВНИЙ СТРЕС У СЛИННИХ ЗАЛОЗАХ ЩУРІВ 3 ГЛУТАМАТІНДУКОВА- НИМ ОЖИРІННЯМ}

Метою дослідження було вивчити вплив наноцерію на про- -антиоксидантний баланс у тканинах слинних залоз у щурів з глутаматіндукованим ожирінням. На 48 щурах лінії Вістар обох статей проведено порівняльне вивчення ефективності внутрішлункового введення нанокристалічного діоксиду церію в дозі 1 мг/кг на фоні глутаматіндукованого ожиріння. Визначена загальна активність NO-синтази, вміст нитритів, ТБК-активних продуктів, окисно-модифікованих білків, а також активність каталази в гомогенатах тканин слинних залоз щурів. Показано, що глутаматіндуковане ожиріння призводить до розвитку окисного стресу в слинних залозах щурів. На фоні дисбалансу про- -антиоксидантної систем в тканинах слюнних залоз щурів з глутаматіндукованим ожирінням, внутрішньошлункове введення нанокристалічного діоксиду церію значно знижувало порівняно з групою тварин без корекції, активність всіх NO-синтаз та вміст нітрат-аніонів. Таким чином, введення наноцерію сприяє корекції патологічних змін у слинних залозах, відновлює про- -антиоксидантну рівновагу в тканинах, попереджаючи активацію NO-ергічних систем.

Ключові слова: нанокристалічний діоксид церію; ожиріння; слинні залози; окисний стрес; глутамат натрію; харчові добавки; тваринна модель.

${ }^{1}$ Київський національний університет імені Тараса Шевченка;

${ }^{2}$ Вищий державний навчальний заклад України «Українська медична стоматологічна академія», Полтава; ${ }^{3}$ Інститут мікробіології і вірусології ім. Д.К. Заболотного НАН України, Київ; e-mail: rostbubnov@gmail.com
Л.П. Гордиенко ${ }^{1}$, Т.В. Береговая ${ }^{1}$, К.С. Непорада ${ }^{2}$, Т.М. Фалалеева ${ }^{1}$, Н.М. Жолобак ${ }^{3}$, А.Б. Щербаков ${ }^{3}$, Р.В. Бубнов ${ }^{3}$, Н.Я. Спивак ${ }^{3}$

\section{НАНОЦЕРИЙ СНИЖАЕТ ОКИСЛИТЕЛЬ- НЫЙ И НИТРОЗАТИВНЫЙ СТРЕСС В СЛЮННЫХ ЖЕЛЕЗАХ КРЫС С ГЛУТАМАТ- ИНДУЦИРОВАННЫМ ОЖИРЕНИЕМ}

Целью исследования было изучить влияние наноцерия на про- -антиоксидантный баланс в тканях слюнных желез у крыс с глутаматиндуцированным ожирением. На 48 крысах линии Вистар обоего пола проведено сравнительное исследование эффективности внутрижелудочного введения нанокристаллического диоксида церия в дозе 1 мг/кг на фоне глутаматиндуцированного ожирения. Определена общая активность NO-синтазы, содержание нитритов, ТБК-активных продуктов, окислительно-модифицированных белков, а также активность каталазы в гомогенате тканей слюнных желез крыс. Показано, что глутаматиндуцированное ожирение приводит к развитию окислительного стресса в слюнных железах крыс. На фоне дисбаланса про- -антиоксидантной систем в тканях слюнных желез крыс с глутаматиндуцированным ожирением, внутрижелудочное введение нанокристаллического диоксида церия значительно снижало, в сравнении с группой животных без коррекции, активность всех NO-синтаз и содержание нитрат-анионов. Таким образом, введение наноцерия способствует коррекции патологических изменений в слюнных железах, восстанавливает про- -антиоксидантное равновесие в тканях, предотвращая активацию NO-эргических систем.

Ключевые слова: нанокристаллический диоксид церия; ожирение; слюнные железы; окислительный стресс; глутамат натрия; пищевые добавки; животная модель.

\section{REFERENCES}

1. Sáez-Lara MJ, Robles-Sanchez C, Ruiz-Ojeda FJ, PlazaDiaz J, Gil A. Effects of probiotics and synbiotics on obesity, insulin resistance syndrome, type 2 diabetes and non-alcoholic fatty liver disease: a review of human clinical trials. Int J Mol Sci. 2016; 17(6). pii: E928. doi: 10.3390/ijms17060928.

2. WHO: Obesity and overweight: Fact sheet N. 311. [http://www.who.int/mediacentre/factsheets/fs311/en/] Accessed 31 May 2017.

3. Zhang Y, Liu J, Yao J, et al. Obesity: Pathophysiology and Intervention. Nutrients. 2014; 6(11):5153-83. doi:10.3390/nu6115153.

4. Husarova V, Ostatnikova D. Monosodium glutamate toxic effects and their implications for human intake: a review. JMED Research, 2013, Article ID 608765, doi: 10.5171/2013.608765.

5. Afifi MM, Abbas AM. Monosodium glutamate versus diet induced obesity in pregnant rats and their offspring. Acta Physiol Hung. 2011 Jun; 98(2):177-88. 
6. Falalieieva TM, Kukhars'ky̌̌ VM, Berehova TV. [Effect of long-term monosodium glutamate administration on structure and functional state of the stomach and body weight in rats]. Fiziol Zh. 2010;56(4):102-10. [Ukrainian].

7. Ashwini R, Priya NK, Nandini DB, Madhushankari GS. Obesity and Oral health - a review. J Dental Pract Res. 2013; 1 (2): 30-5.

8. Ueda H, Yagi T, Amitani $\mathrm{H}$ et al. The roles of salivary secretion, brain-gut peptides, and oral hygiene in obesity. Obes Res Clin Pract. 2013; 7 (5): 321-9.

9. Mozaffari MS, Abdelsayed R, Zakhary I, et al. Submandibular gland and caries susceptibility in the obese Zucker rat. J Oral Pathol Med. 2011; 40 (2): 194-200.

10. Guare RO, Ciamponi AL, Santos MT. Caries experience and salivary parameters among overweight children and adolescents. Dent. J. 2013; 1: 31-40. doi:10.3390/ dj1040031

11. Savini I, Catani MV, Evangelista D, Gasperi V, Avigliano L. Obesity-associated oxidative stress: strategies finalized to improve redox state. Int J Mol Sci. 2013: 14 (5): 10497-538. doi: 10.3390/ijms140510497.

12. Nelson BC, Johnson ME, Walker M.L, Riley KR, Sims C.M. Antioxidant cerium oxide nanoparticles in biology and medicine. Antioxidants. 2016; 5 (15): 1-21. doi:10.3390/antiox5020015.

13. Finkel T. Signal transduction by reactive oxygen species. J Cell Biol. 2011; 194 (1): 7-15.

14. Iefimenko OY, Savchenko IO, Falalyeyeva TM, Beregova TV, Zholobak NM, Shcherbakov OB, et al. The influence of nanodisperse cerium dioxide on ontogenetic changes of antioxidant system in the mucosa of the stomach and colon in rats. Fiziol Zh. 2015;61(3):44-50. [Ukrainian].

15. Kobyliak NM, Falalyeyeva TM, Kuryk OG, Beregova TV, Bodnar PM, Zholobak NM, Shcherbakov OB, Bubnov RV, Spivak MY. Antioxidative effects of cerium dioxide nanoparticles ameliorate age-related male infertility: optimistic results in rats and the review of clinical clues for integrative concept of men health and fertility. EPMA J. 2015;6:12. doi: 10.1186/s13167-015-0034-2 .

16. Shcherbakov AB, Zholobak NM, Ivanov VK, Tret' yakov YD, Spivak NY. Nanomaterials based on the nanocrystalline ceria: properties and use perspectives in biology and medicine. Biotechnologia Acta. 2011;4(1):9-28

17. Naganuma T, Traversa E. Stability of the Ce3+ valence state in cerium oxide nanoparticle layers. Nanoscale. 2012; 4(16):4950-3.

18. Wong LL, McGinnis JF. Nanoceria as bona fide catalytic antioxidants in medicine: what we know and what we want to know. Adv Exp Med Biol. 2014; 801 (1): 821-8.

19. Heckman KL, De Coteau W, Estevez A, Reed KJ, Costanzo W. Custom cerium oxide nanoparticles protect against a free radical mediated autoimmune degenerative disease in the brain. ACS Nano. 2013; 7(12): 10582-96.

20. Lee SS, Song W, Cho M, Puppala HL, Nguyen P. Antioxidant properties of cerium oxide nanocrystals as a function of nanocrystal diameter and surface coating.
ACS Nano. 2013; 7(11): 9693-703.

21. Chen S, Hou Y, Cheng G, Zhang C, Wang S. Cerium oxide nanoparticles protect endothelial cells from apoptosis induced by oxidative stress. Biol Trace Elem Res. 2013; 154(1): 156-66.

22. Beregova TV, Neporada KS, Skrypnyk M, Falalyeyeva TM, Zholobak NM, Shcherbakov OB, Spivak MY, Bubnov RV. Efficacy of nanoceria for periodontal tissues alteration in glutamate-induced obese rats-multidisciplinary considerations for personalized dentistry and prevention. EPMA J. 2017 Mar 14;8(1):43-49. doi: 10.1007/s13167017-0085-7.

23. Savcheniuk OA, Virchenko OV, Falalyeyeva TM, Beregova TV, Babenko LP, Lazarenko LM, Demchenko OM, Bubnov RV, Spivak MY. The efficacy of probiotics for monosodium glutamate-induced obesity: dietology concerns and opportunities for prevention. EPMA Journal 2014, 5:2.

24. Hevel JM. Purification of the inducible murene machrophage nitric oxide synthase. J Biol Chem. 1991; 266(34): 22789-91.

25. Stalnaya ID, Garishvili TG. Method for determination of malondialdehyde using the thiobarbituric acid. Modern methods in biochemistry. Moscow: Medicine; 1977:668. [Russian].

26. Dubinina EE, Burmistrov SO. Oxidative modification of proteins of human serum. Method of determining. Questions of medicinal chemistry. 1995; 1: 24-6. [Russian].

27. Koroliuk MA, Ivanov LI, Mayorov YH. Method for determining of catalase activity. Laboratornoe delo. 1988;(1): 16-9. [Russian].

28. Liu GS, Chan EC, Higuchi M, Dusting GJ, Jiang F. Redox mechanisms in regulation of adipocyte differentiation: beyond a general stress response. Cells 1. 2012; 4: 976-93.

29. Rocca A, Moscato S, Ronca F, Nitti S, Mattoli V, et al. Pilot in vivo investigation of cerium oxide nanoparticles as a novel anti-obesity pharmaceutical formulation. Nanomedicine. 2015; 11 (7):1725-34. doi: 10.1016/j. nano.2015.05.001.

30. Christine JW, Joseph JC. Measurement of superoxide dismutase, catalase, and glutathione peroxidase in cultured cells and tissue. Nat Protoc. 2010; 5(1): 51-66. doi:10.1038/nprot.2009.197.

31. Bryant CN, Monique EJ, Marlon LW, Kathryn RR, Christopher MS. Review Antioxidant cerium oxide nanoparticles in biology and medicine. Antioxidants. 2016; 5(15). doi:10.3390/antiox5020015.

32. Zalewska A, Kna's M, Waszkiewicz N, Klimiuk A, Litwin $\mathrm{K}$, et al. Salivary antioxidants in patients with systemic sclerosis. J. Oral Pathol. Med. 2014; 43: 61-8.doi:10.1111/ jop. 12084.

33. Goldschmidt-Clermont PJ, Moldovan L. Stress, superoxide, and signal transduction. Gene Expression. 1999; 7(4-6): 255-60.

34. Matsushita K, Morrell CN, Mason RJ, Yamakuchi M, Khanday FA, et al. Hydrogen peroxide regulation of 
endothelial exocytosis by inhibition of $\mathrm{N}$-ethylmaleimide sensitive factor. The Journal of Cell Biology. 2005; 170 (1): 73-9.

35. Abdollahi M, Fooladian F, Emami B, Zafari K, BahreiniMoghadam A. (2003). Protection by sildenafil and theophylline of lead acetate-induced oxidative stress in rat submandibular gland and saliva. Human \& Experimental Toxicology. 2003; 22 (11): 587-92.

36. Takeda I, Kizu Y, Yoshitaka O, Saito I, Yamane GY. Possible role of nitric oxide in radiation-induced salivary gland dysfunction. Radiation Research. 2003; 159 (4): 465-70.

37. Kołodziej U, Maciejczyk M, Miasko A, Matczuk J, MKna' $\mathrm{s} \mathrm{M}$, et al. Oxidative modification in the salivary glands of high fat-diet induced insulin resistant rats. Front. Physiol. 2017; 8(20): 1-20. doi: 10.3389/fphys.2017.00020.

38. Manisundar N, Julius A, A. Amudhan A., et al. Nitric oxide as an inflammatory biomarker in oral and systemic diseases - a systematic review. Middle-East Journal of Scientific Research. 2014; 20 (7): 881-6.

39. Pirmohamed T, Dowding JM, Singh S, Wasserman B, Heckert E. Nanoceria exhibit redox state-dependent catalase mimetic activity. Chem Commun (Camb). 2010; 46 (16): 2736-38.

40. Xia T, Kovochich M, Liong M, Mädler L. Comparison of the mechanism of toxicity of zinc oxide and cerium oxide nanoparticles based on dissolution and oxidative stress properties. ACS Nano. 2008; 2(10): 2121-34. 